J. Dairy Sci. 96:7195-7209

http://dx.doi.org/10.3168/jds.2013-6889

(c) American Dairy Science Association ${ }^{\circledR}, 2013$.

\title{
Unique interrelationships between fiber composition, water-soluble carbohydrates, and in vitro gas production for fall-grown oat forages ${ }^{1}$
}

\author{
W. K. Coblentz, ${ }^{2}$ S. E. Nellis, † P. C. Hoffman,† M. B. Hall,‡ P. J. Weimer,‡ N. M. Esser,§ and M. G. Bertram\# \\ *US Department of Agriculture-Agricultural Research Service, US Dairy Forage Research Center, Marshfield, WI 54449 \\ †Department of Dairy Science, University of Wisconsin, Madison 53706 \\ fUS Department of Agriculture-Agricultural Research Service, US Dairy Forage Research Center, Madison WI 53706 \\ §University of Wisconsin Marshfield Agricultural Research Station, Marshfield 54449 \\ \#University of Wisconsin Arlington Agricultural Research Station, Arlington 53911
}

\section{ABSTRACT}

Sixty samples of 'ForagePlus' oat were selected from a previous plot study for analysis of in vitro gas production (IVGP) on the basis of 2 factors: (1) high (n $=29)$ or low $(\mathrm{n}=31)$ neutral detergent fiber (NDF; $62.7 \pm 2.61$ and $45.1 \pm 3.91 \%$, respectively); and (2) the range of water-soluble carbohydrates (WSC) within the high- and low-NDF groups. For the WSC selection factor, concentrations ranged from 4.7 to $13.4 \%$ (mean $=7.9 \pm 2.06 \%$ ) and from 3.5 to $19.4 \%$ (mean $=9.7 \pm$ $4.57 \%$ ) within high- and low-NDF forages, respectively. Our objectives were to assess the relationships between IVGP and various agronomic or nutritional characteristics for high- and low-NDF fall-oat forages. Cumulative IVGP was fitted to a single-pool nonlinear regression

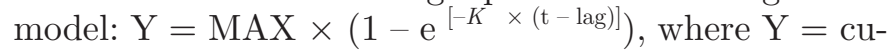
mulative gas produced $(\mathrm{mL}), \mathrm{MAX}=$ maximum cumulative gas produced with infinite incubation time $(\mathrm{mL})$, $K=$ rate constant, $\mathrm{t}=$ incubation time $(\mathrm{h})$, and lag $=$ discrete lag time (h). Generally, cumulative IVGP after $12,24,36$, or $48 \mathrm{~h}$ within high-NDF fall-oat forages was negatively correlated with NDF, hemicellulose, lignin, and ash, but positively correlated with WSC, nonfiber carbohydrate (NFC), and total digestible nutrients (TDN). For low-NDF fall-grown oat forages, IVGP was positively correlated with growth stage, canopy height, WSC, NFC, and TDN; negative correlations were observed with ash and crude protein $(\mathrm{CP})$ but not generally with fiber components. These responses were also reflected in multiple regression analysis for high- and low-NDF forages. After 12,24 , or $36 \mathrm{~h}$ of incubation, cumulative IVGP within high-NDF fall-oat forages was

Received April 2, 2013.

Accepted July 13, 2013.

${ }^{1}$ Mention of trade names or commercial products in this article is solely for the purpose of providing specific information, and does not imply either recommendation or endorsement by the US Department of Agriculture.

${ }^{2}$ Corresponding author: wayne.coblentz@ars.usda.gov explained by complex regression equations utilizing (lignin:NDF) ${ }^{2}$, lignin:NDF, hemicellulose, lignin, and $\mathrm{TDN}^{2}$ as independent variables $\left(\mathrm{R}^{2} \geq 0.43\right)$. Within low-NDF fall-grown oat forages, cumulative IVGP at these incubation intervals was explained by positive linear relationships with NFC that also exhibited high coefficients of determination $\left(\mathrm{R}^{2} \geq 0.75\right)$. Gas production was accelerated at early incubation times within low-NDF forages, specifically in response to large pools of WSC that were most likely to be present as forages approached boot stage by late-fall.

Key words: fiber composition, in vitro gas production, oat, water-soluble carbohydrate

\section{INTRODUCTION}

Recently, several research projects have evaluated the potential of fall-grown oat (Avena sativa L.) for use as an emergency fall forage, to extend the grazing season, or for routine use as an additional unique forage option for dairy and other livestock producers located in the north-central United States (Contreras-Govea and Albrecht, 2006; Coblentz and Walgenbach, 2010; Coblentz et al., 2011). Although the fall yield potential has proven to be encouraging, reaching maxima $>8,000$ $\mathrm{kg}$ of $\mathrm{DM} / \mathrm{ha}$ under favorable weather conditions (Coblentz et al., 2011), several unique quality traits have also been identified consistently and warrant additional in-depth evaluation. Among these are reduced concentrations of structural fiber components, less extensive lignification, and a propensity to accumulate water-soluble carbohydrates (WSC) during late fall (ContrerasGovea and Albrecht, 2006; Coblentz and Walgenbach, 2010; Coblentz et al., 2012).

Several interrelated management, weather, and plant-physiology factors contribute to the expression of these unique forage-quality traits. When oat is grown during fall, the long-day photoperiod requirement for flowering (Dennis, 1984) is disrupted, thereby altering normal plant maturation and development. These natural developmental processes are further affected by 
the onset of cold temperatures and frost events. Collectively, these factors act to slow maturation relative to normal responses following traditional spring planting dates. Contreras-Govea and Albrecht (2006) reported that 3 oat cultivars evaluated after a traditional spring planting date reached the mid-milk stage of grain fill 77 $\mathrm{d}$ after planting, whereas the same cultivars evaluated following an August planting date were far less mature after an identical time interval, reaching only the mid-boot stage of growth. In addition, the process of winter-hardening occurs within oat plants in response to cold temperatures. As a result, various solutes accumulate within plant tissues that include sugars (Eastin and Sullivan, 1984), some of which exist in the form of fructans for oat (Smith, 1981). Depending on planting date and cultivar selection, concentrations of WSC can exceed $15 \%$ of total plant DM by November (Coblentz et al., 2012). Furthermore, a positive relationship between temperature and lignification exists for many forages (Ford et al., 1979; Van Soest, 1982); therefore, it is reasonable to suspect that oat plants grown during fall should be lignified less extensively than comparable plants maturing during late spring or early summer. Cherney et al. (1983) reported lignin:NDF ratios of 0.074 to 0.106 for spring-established oat harvest 7 to 28 d postheading, and NRC (2001) reports similar ratios of 0.112 and 0.091 for headed oat hays and silages, respectively. In contrast, lignin:NDF ratios are often reduced by $50 \%$ or more within fall-grown oat forages, and particularly when seeding dates are delayed in Wisconsin until August (Coblentz and Walgenbach, 2010; Coblentz et al., 2012). In one study, ForagePlus oat (Wisconsin Foundation Seeds, Madison, WI) established in early August and harvested on several dates throughout the fall exhibited mean lignin:NDF ratios of 0.010 and 0.020 during 2006 and 2007, respectively (Coblentz and Walgenbach, 2010). Reductions of the lignin:NDF ratio also have a positive effect on estimates of in vitro NDF digestibility, which has been closely associated with lignin concentrations for fall-grown oat forages $\left(\mathrm{Y}=0.64 \mathrm{x}^{2}-11.9 \mathrm{x}+89.1 ; \mathrm{R}^{2}=0.95\right.$; Coblentz et al., 2012).

These physiological responses for fall-grown oat can be manipulated further by various production management options, such as cultivar selection and planting date. Generally, maturity ratings such as early, mid, or late are based on growth and maturation responses following traditional spring establishment (Mochon and Conley, 2012). These relative maturity rankings also are maintained during fall growth, but differences in maturation rate between rating categories are often exacerbated (Coblentz et al., 2011). Establishment dates also can interact with relative maturity rankings, thereby complicating management strategies. For in- stance, late-maturing forage cultivars, such as ForagePlus, are the best management choice for planting dates ranging from mid-July to early August throughout central Wisconsin, but faster maturing grain cultivars may exhibit yield advantages with later establishment dates (Coblentz and Walgenbach, 2010). Furthermore, concentrations of WSC are dependent on both of these management factors; oat plants exposed to cold temperatures at the late-elongation or boot stages of growth frequently exhibit the greatest concentrations of WSC (Coblentz et al., 2012).

Despite undergoing winter-hardening, oat plants are unlikely to survive northern United States winters; however, their fall growth can still be utilized to meet various production goals. Furthermore, the substantial accumulations of WSC within these forage plants raise interesting questions about how ruminal fermentation may be affected. Potentially, accumulations of large quantities of WSC within elongated or boot-stage plants may shift the normal production paradigm in which DM yield and forage nutritive value are inversely related. Typically, management strategies require compromises between yield and nutritive value, but this may not be true for fall-grown oat. Our objectives were to assess the relationships between various agronomic or nutritional characteristics and in vitro gas production (IVGP) for high- and low-NDF fall-grown oat forages selected from a previous 3-yr project (Coblentz et al., 2011, 2012) conducted in Marshfield, Wisconsin. In vitro gas production was selected as a means of comparing rumen fermentation because it permitted rapid analysis of many samples, and is known to correlate strongly with VFA production (O'Hara and Ohki, 1973; Blümmel et al., 1994), and thus delivery of primary nutrients (VFA) to the animal during ruminal fermentation.

\section{MATERIALS AND METHODS}

\section{Selection of Forages}

The oat forages evaluated for this project were all grown in fall, and were a subset selected from a larger 3-yr plot study evaluating establishment dates, cultivar selection, and harvest dates conducted at the University of Wisconsin Marshfield Agricultural Research Station $\left(44^{\circ} 39^{\prime} \mathrm{N} ; 90^{\circ} 08^{\prime} \mathrm{W}\right)$ between 2007 and 2009. Full details describing experimental design, plot and harvest management, and assessment of nutritive value for these forages have been reported previously (Coblentz et al., 2011, 2012). A linear model (Stauss, 1994) was used to describe the growth stage of each forage at the time it was harvested. In this model, growth stages were defined as follows: (1) leaf development, 10-19; 
Table 1. Summary statistics for fall-grown oat forages harvested from 2007 to $2009^{1}$

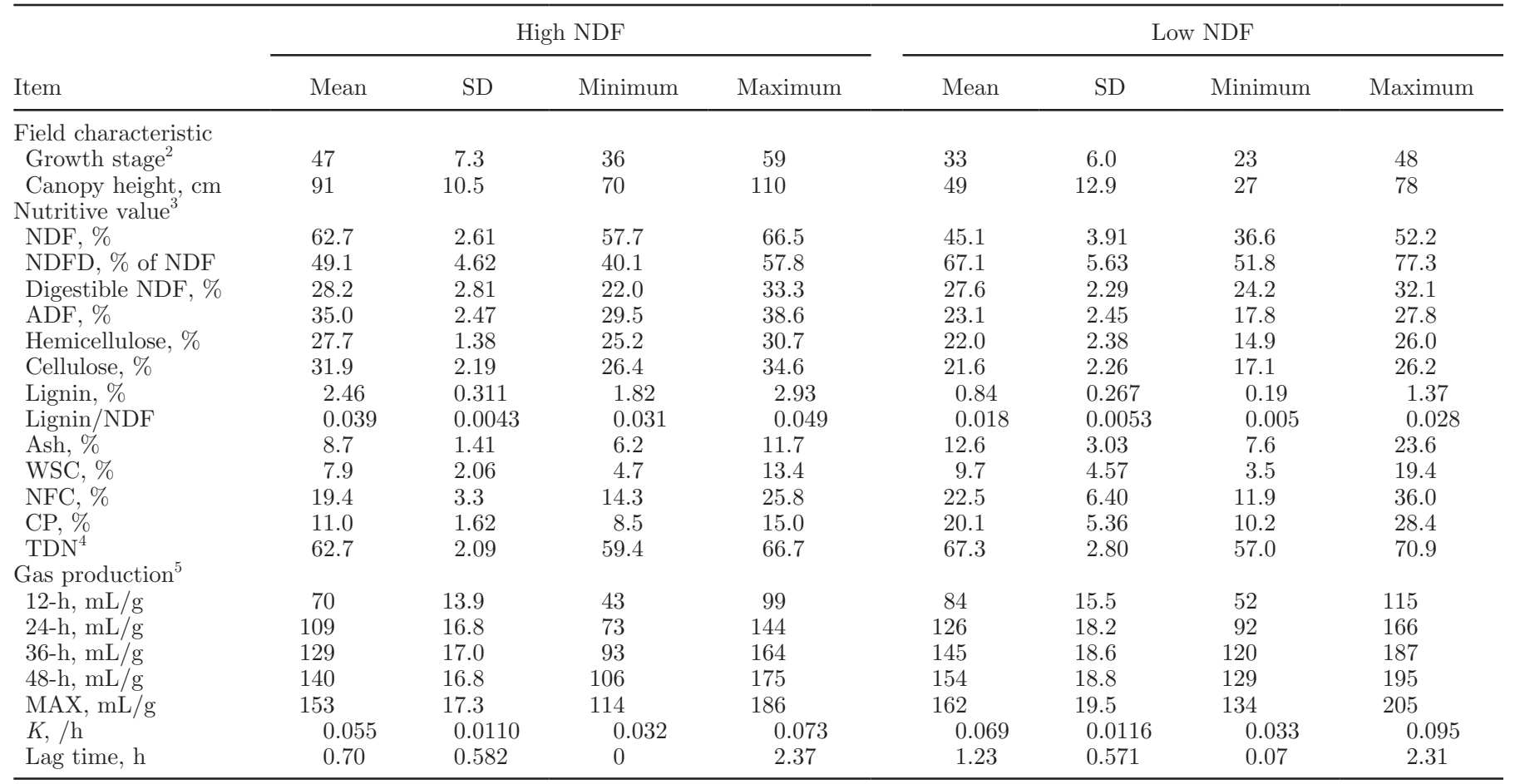

${ }^{1}$ Forages were segregated on the basis of NDF concentrations with high- and low-NDF groups containing 29 and 31 forages, respectively.

${ }^{2}$ Linear scale to describe growth stage of oat plants at harvest (10 to 19, leaf development; 20 to 29, tillering; 30 to 39 , stem elongation; 40 to 49, boot stage; and 50 to 59, heading; Stauss, 1994).

${ }^{3} \mathrm{NDFD}=48$-h in vitro NDF digestibility; WSC $=$ water-soluble carbohydrates.

${ }^{4}$ Calculated with the lignin option for determining truly digestible fiber (NRC, 2001).

${ }^{5} 12$ - $\mathrm{h}, 24$ - $\mathrm{h}, 36$ - $\mathrm{h}$, and 48 - $\mathrm{h}=$ cumulative in vitro gas production (IVGP) after 12, 24, 36, and $48 \mathrm{~h}$, respectively; MAX = theoretical maximum cumulative IVGP based on nonlinear regression; $K=$ rate of IVGP.

(2) tillering, 20 to 29; (3) stem elongation, 30 to $39 ;(4)$ boot stage, 40 to 49; and (5) heading, 50 to 59. For the current project, individual plot samples of 'ForagePlus' oat (Wisconsin Foundation Seeds) were selected for additional evaluation of IVGP on the basis of 2 factors: (1) high or low concentrations of NDF (62.7 \pm 2.61 and $45.1 \pm 3.91 \%$, respectively; Table 1 ); and (2) the range of concentrations of WSC within the high- and lowNDF groups. A $t$-test (PROC TTest; SAS version 9.2, SAS Institute Inc., Cary, NC) indicated that the mean NDF concentrations for the 2 NDF groups differed $(P$ $<0.001$ ). Concentrations of WSC ranged from 4.7 to $13.4 \%(\mathrm{n}=29$; mean $=7.9 \pm 2.06 \%)$ for high-NDF oat forages, and from 3.5 to $19.4 \%(\mathrm{n}=31$; mean $=9.7 \pm$ $4.57 \%$ ) for low-NDF oat forages. Initially, all selections for the present study were based on nutritional analyses determined by near-infrared reflectance spectroscopy that were reported previously (Coblentz et al., 2012); however, these analyses were not used or reported within the current project, and all relationships discussed hereafter are based on results obtained from traditional laboratory methods after the initial sample selections were completed. The IVGP assessments also were limited to only one cultivar (ForagePlus), largely to eliminate unnecessary confounding or complexity related to differences in maturation rates across cultivars.

\section{Laboratory Analyses}

All fall-grown oat forages were hand-clipped from plots $(\sim 500 \mathrm{~g})$, and then dried to constant weight under forced air at $55^{\circ} \mathrm{C}$. Samples were ground through a 1-mm screen with a Thomas Model 4 Wiley mill (Thomas Scientific, Swedesboro, NJ) and then stored in sealed plastic sample bags pending analysis for nutritive composition. Forage samples were analyzed sequentially for NDF, ADF, hemicellulose, cellulose, and ADL using batch procedures outlined by Ankom Technology Corp. (Macedon, NY) for an Ankom ${ }^{200}$ Fiber Analyzer. Heat-stable $\alpha$-amylase was included in the NDF solution, but sodium sulfite was omitted. Crude protein was determined by a rapid combustion procedure (AOAC International, 1998; method 990.03; Elementar Americas Inc., Mt. Laurel, NJ) as the per- 
centage of $\mathrm{N} \times 6.25$. Concentrations of whole-plant ash were obtained from 1.0-g subsamples of each selected forage following combustion in a muffle furnace at $500^{\circ} \mathrm{C}$ for $6 \mathrm{~h}$. Water-soluble carbohydrates were extracted from ground forage by suspending $0.25-\mathrm{g}$ samples of each forage in $150 \mathrm{~mL}$ of deionized water for $2 \mathrm{~h}$, and then filtering through Whatman \#1 filter paper (GE Healthcare UK Ltd., Little Chalfont, UK). The phenolsulfuric acid reaction was used to quantify WSC within aliquots of the filtered extract; final concentrations of WSC were determined colorimetrically (Dubois et al., 1956). Energy density (TDN) and NFC were calculated for all forages based on the summative equation (Weiss et al., 1992; NRC, 2001); the ADL option was used to estimate truly digestible fiber.

Organic acids were extracted from 1.0-g subsamples of 2 selected fall-oat forages obtained from the same research plot, but harvested on early (September 15; late-vegetative stage) and late (November 3; early-boot stage) dates during 2008. The ground forages were suspended in $25 \mathrm{~mL}$ of McDougall buffer by stirring for $1 \mathrm{~h}$ at $39^{\circ} \mathrm{C}$. The suspension was then centrifuged $\left(12,000 \times g, 10 \mathrm{~min}, 4^{\circ} \mathrm{C}\right)$, and the supernatant was treated with calcium hydroxide and copper sulfate to remove sugars and proteins (Siegfried et al., 1984). The resulting supernatant was analyzed by HPLC (Weimer et al., 1991). Retention times for the organic acids were as follows: (1) maleic, $8.17 \mathrm{~min}$; (2) malonic, $8.96 \mathrm{~min}$; (3) malic, $9.36 \mathrm{~min}$; (4) succinic, $10.89 \mathrm{~min}$; and (5) fumaric, $13.47 \mathrm{~min}$. For these HPLC determinations, crotonic acid was used as an internal standard.

\section{In Vitro Gas Production}

Fermentation System. In vitro gas production was measured using the Ankom-RFS system (Ankom Technology Corp.). The system consisted of 24 incubation flasks fitted with wireless transponders (Leibovich et al., 2009). All incubations were conducted in a controlledtemperature incubation room maintained at $39^{\circ} \mathrm{C}$. In vitro procedures for preparation of rumen buffer, macromineral, micromineral, and reducing solutions, as well as additions of resazurin and trypticase were consistent with those described by Goering and Van Soest (1970). Rumen fluid was harvested from 2 lactating cows consuming a TMR diet composed of (DM basis) $22.2 \%$ corn silage, $21.1 \%$ high-moisture corn, $20.2 \%$ alfalfa haylage, $8.5 \%$ alfalfa balage, and $5.2 \%$ whole cottonseed, and the balance consisted of protein and mineral supplements. Analysis of the blended diet was $52.3 \%$ DM, $17.3 \%$ CP, $30.9 \%$ NDF, $21.2 \%$ ADF, $42.3 \%$ NFC, and $75.1 \%$ TDN (University of Wisconsin Soil and Forage Laboratory, Marshfield). After collection, rumen fluid was maintained at $39^{\circ} \mathrm{C}$, strained through
3 layers of cheesecloth, mixed with equal contributions from each of the 2 cows, gassed with $\mathrm{CO}_{2}$, and injected into the individual incubation flasks. The substrate within each flask was a 0.5 -g sample of fall-oat forage that was corrected for DM concentration for all subsequent calculations; substrates were freely suspended within the incubation medium, and were not confined within filter bags. Gas pressure from each flask was recorded at 0.25 -h intervals for $48 \mathrm{~h}$. Pressure values were then adjusted for gas pressures obtained from duplicate blank (no substrate) flasks that were evaluated during the same laboratory run. Adjusted gas pressures then were converted mathematically to cumulative milliliters of gas produced (Ankom Technology Corp., 2012) and expressed on a milliliters per gram of DM basis.

In vitro incubations of the 60 selected oat forages were performed across 10 laboratory incubation runs, such that each run evaluated about 22 different oat samples and 2 blanks (no substrate). Furthermore, each sample was evaluated within 4 of the 10 different incubation runs, but randomization was employed to ensure that the within-run sample partners for any individual sample were varied each time it was evaluated. During sample assignments to incubation runs, high- and low-NDF designations were not considered. For each oat sample, the cumulative amount $(\mathrm{mL})$ of gas produced at each 0.25 -h sampling interval was averaged over the 4 laboratory runs before curve fitting procedures were applied. It was expected that IVGP curves would be multi-phasic in nature because of the different fermentation kinetics associated with WSC and NDF. Initially, our goal was to capture as much of this information as possible by using a multi-phasic regression model, such as those described by Groot et al. (1996), to fit the IVGP data. However, preliminary attempts to find a single multi-phasic model that could be applied to the diverse gas-production responses observed across all oat samples proved to be problematic; therefore, a single-phase model was used such that gasproduction responses for all samples could be fit to the same model. Although this approach likely obscured some useful information, it allowed an unbiased comparison of gas-production responses across all samples. Within this context, the cumulative IVGP response for each sample (mL/g of DM) was fitted by PROC NLIN (version 9.2, SAS Institute Inc.) to a one-pool model defined as follows: $\mathrm{Y}=\operatorname{MAX} \times\left(1-\mathrm{e}^{[-K \times(\mathrm{t}-\mathrm{lag})]}\right)$, where $\mathrm{Y}=$ cumulative gas produced at any incubation time $(\mathrm{mL}), \mathbf{M A X}=$ maximum cumulative gas produced with infinite incubation time $(\mathrm{mL}), \boldsymbol{K}=$ rate constant, $\mathbf{t}=$ incubation time $(\mathrm{h})$, and lag $=$ discrete lag time (h) associated with initiation of IVGP. When any nonlinear regression fitted a lag time of $<0.01 \mathrm{~h}$, the discrete lag time was dropped from the model, and 
it was assumed that IVGP began without a lag time (0 h). To facilitate interpretation of the data, the nonlinear regression model fitted for each oat sample was then used to generate a predicted cumulative IVGP volume after $12,24,36$, and $48 \mathrm{~h}$ of incubation; responses at these time points were expected to vary substantially, depending on the relative proportions of NDF, WSC, and other fermentation substrates within the forage.

Determination of In Vitro NDF Digestibility. In vitro NDF digestibility (NDFD) was determined after the 48-h incubation for IVGP by adding $50 \mathrm{~mL}$ of NDF solution to the contents of each flask, quantitatively transferring the contents to a $600-\mathrm{mL}$ Berzelius beaker, boiling under reflux for $1 \mathrm{~h}$, and then filtering with vacuum onto Whatman 54 filter paper (GE Healthcare UK Ltd.). Both heat-stable $\alpha$-amylase and sodium sulfite were added to the NDF solution. Digestibility of NDF was based on an independent determination of NDF for each original sample also using both heat-stable $\alpha$-amylase and sodium sulfite within the NDF solution.

\section{Statistics}

Gas production parameters (cumulative IVGP at 12 , 24,36 , and $48 \mathrm{~h}$, as well as MAX, $K$, and discrete lag time) were correlated with growth stage, canopy height, and nutritive composition using PROC CORR of SAS (version 9.2, SAS Institute Inc.). Correlations were evaluated for the high- $(\mathrm{n}=29)$ and low- $(\mathrm{n}=$ 31) NDF subgroups independently. Multiple regression relationships between IVGP parameters and nutritive composition were established with PROC REG (SAS Institute Inc.) using the stepwise option; criteria for entry and retention in the model were set at $P=0.1$. Independent variables, such as NDF, WSC, and so on, were squared for potential consideration in the multiple regression models. All other (linear) regressions were conducted with PROC REG (SAS Institute Inc.), and (where appropriate) linear responses for high- and lowNDF groups were tested for homogeneity of slopes and intercepts using PROC GLM. For correlation analysis and linear regressions, significance was declared at $P<$ 0.05 unless otherwise noted.

\section{RESULTS}

\section{Relationships of High- and Low-NDF Sample Groups to Growth Characteristics}

Following traditional spring establishment of oat, a positive association between NDF and plant morphology or canopy height should be expected, largely because mature or elongated plants are generally taller than immature or vegetative plants, and thus have a greater proportion of stem relative to leaf tissue. Considered collectively, the relationships between NDF and growth stage or canopy height for our selected fall-oat forages appear to be consistent with this premise (Figures 1A and $1 \mathrm{~B}$ ). The linear regression of NDF on growth stage for all 60 oat forages $\left(\mathrm{Y}=0.73 \mathrm{x}+24.3 ; \mathrm{R}^{2}=0.55\right)$, as well as a similar regression on canopy height $(\mathrm{Y}=$ $\left.0.36 \mathrm{x}+28.7 ; \mathrm{R}^{2}=0.84\right)$, suggest agreement with expected positive relationships between NDF and either plant maturity or canopy height. However, for fall oat, this perspective was largely an artifact of the 2 distinct selected populations, and mostly spurious. For highNDF forages, linear growth stage ranged widely from 36 (late stem elongation) to 59 (full head emergence), and canopy height from 70 to $110 \mathrm{~cm}$; however, NDF was not related to either growth characteristic $(P \geq$ $0.15)$. Within low-NDF fall oat, a positive relationship existed between NDF and both growth characteristics; however, canopy height only explained about half of the variation in NDF across this group ( $\mathrm{Y}=0.22 \mathrm{x}$ $\left.+34.1 ; \mathrm{R}^{2}=0.54\right)$, and the relationship with growth stage was poorer $\left(\mathrm{Y}=0.40 \mathrm{x}+31.9 ; \mathrm{R}^{2}=0.37\right)$. Linear relationships between lignin and growth characteristics (data not shown) followed patterns similar to those observed for NDF; across all samples, positive linear relationships were detected for both growth stage (Y $\left.=0.068 \mathrm{x}-1.11 ; \mathrm{R}^{2}=0.57\right)$ and canopy height $(\mathrm{Y}=$ $\left.0.033 \mathrm{x}-0.63 ; \mathrm{R}^{2}=0.83\right)$, which are consistent with expectations for advancing maturation in forages. However, these relationships were largely spurious and artifacts of establishing a linear regression through 2 distinct NDF groups. Although significant regressions $(P<0.001)$ were observed for low-NDF forages, we found no relationship $(P=0.82)$ between lignin and growth stage for high-NDF forages, and the corresponding relationship between lignin and canopy height was poor $\left(\mathrm{Y}=0.012 \mathrm{x}+1.38 ; \mathrm{R}^{2}=0.16\right)$.

Similarly, NDFD was inversely related to growth stage (Figure $2 \mathrm{~A} ; \mathrm{Y}=-0.81 \mathrm{x}+90.4 ; \mathrm{R}^{2}=0.54$ ) and canopy height (Figure $2 \mathrm{~B} ; \mathrm{Y}=-0.37 \mathrm{x}+84.2 ; \mathrm{R}^{2}=$ $0.75)$ when oat forages were considered collectively, but no relationship $(P \geq 0.14)$ was found within high-NDF fall oat in either case, and coefficients of determination for low-NDF oat explained only about $30 \%$ of the variation in NDFD. However, NDFD was closely associated with concentrations of lignin (Figure 2C). Across all fall-oat forages, NDFD was inversely related to lignin $\left(\mathrm{Y}=-10.8 \mathrm{x}+75.9 ; \mathrm{R}^{2}=0.81\right)$, and tests of homogeneity indicated that neither slopes $(P=0.46)$ nor intercepts $(P=0.26)$ differed across NDF designations.

An important hypothesis for this study was that the widely ranging concentrations of WSC (3.5 to $19.4 \%$; Table 1) would have a substantial, and likely positive, 
A

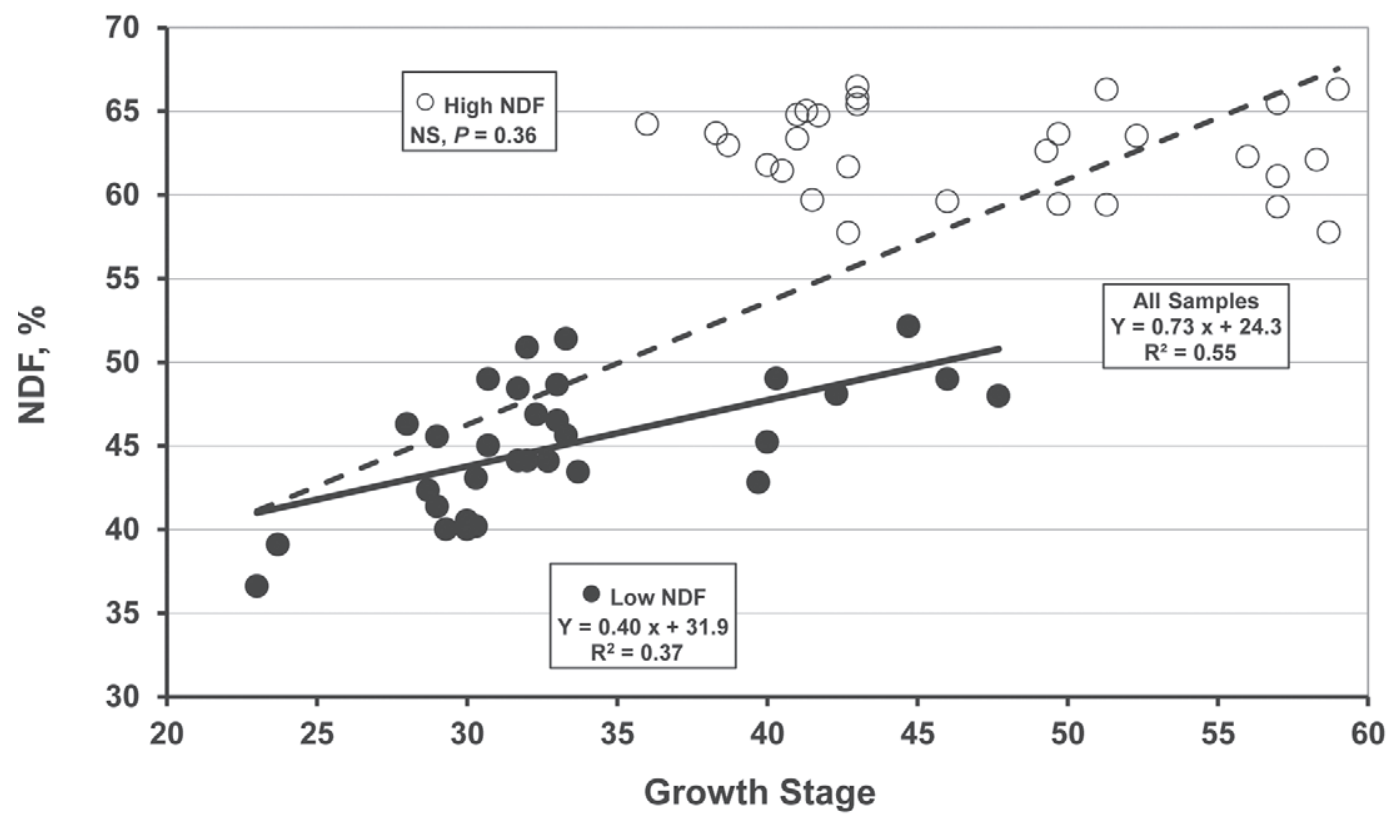

B

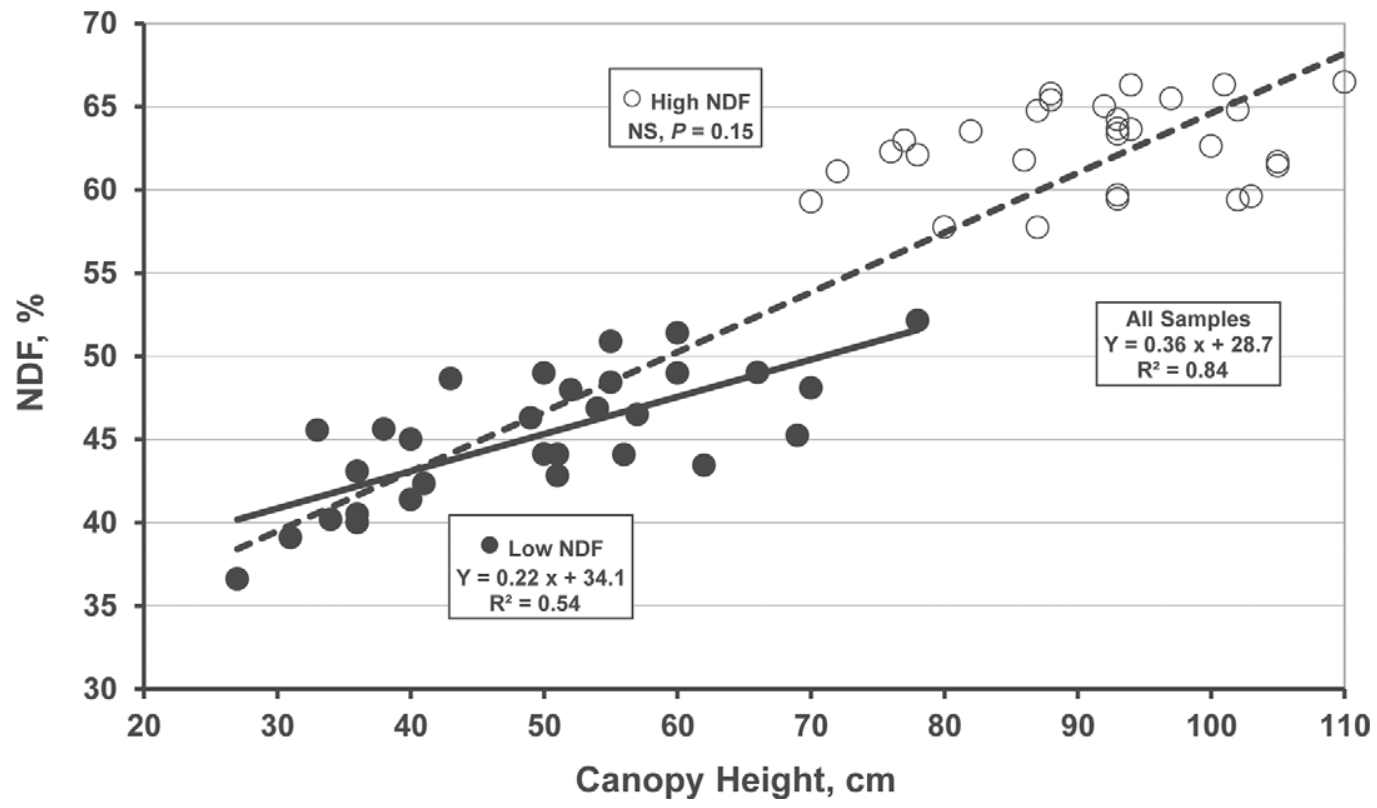

Figure 1. Linear relationships between concentrations of NDF and growth stage (A) or canopy height (B) for 60 fall-grown oat forages harvested from 2007 to 2009 at Marshfield, Wisconsin. Forages are divided on the basis of NDF concentration, where low NDF ( $\mathrm{n}=31$ ) ranged from 36.6 to $52.2 \%$ (mean $=45.1 \pm 3.91 \%)$ and high NDF $(\mathrm{n}=29)$ ranged from 57.7 to $66.5 \%$ (mean $=62.7 \pm 2.61 \%)$. Growth stages are defined as follows: 10 to 19, leaf development; 20 to 29, tillering; 30 to 39, stem elongation; 40 to 49, boot stage; and 50 to 59, heading (Stauss, 1994).

effect on IVGP responses. Therefore, identification of any obvious relationship between WSC and growth characteristics (Figure 3) could be important for maximizing in vitro fermentation. Within low-NDF oat forages, positive relationships were detected between WSC and growth stage $\left(\mathrm{Y}=0.54 \mathrm{x}-8.2 ; \mathrm{R}^{2}=0.50\right)$, as well as canopy height $\left(\mathrm{Y}=0.19 \mathrm{x}+0.4 ; \mathrm{R}^{2}=0.29\right)$; however, linear relationships within high-NDF oat forages, or all 60 forages combined, did not approach significance $(P \geq 0.25)$.

\section{Gas Production and Correlation Analysis}

Gas Production. Overall, we observed a wide range of IVGP responses across the 60 oat forages. Estimates 

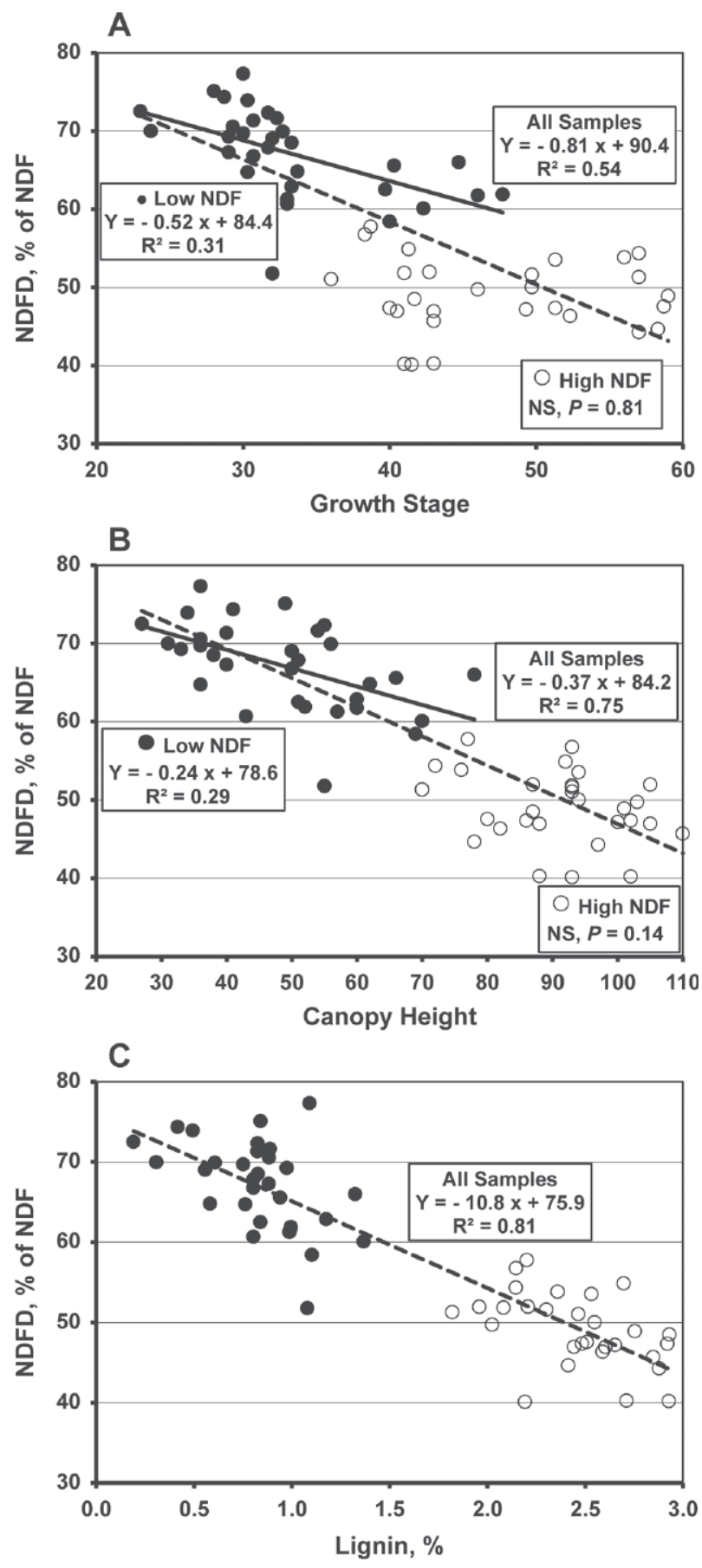

Figure 2. Linear relationships between in vitro NDF digestibility (NDFD) and growth stage (A), canopy height (B), or acid-detergent lignin (C) for 60 fall-grown oat forages harvested from 2007 to 2009 at Marshfield, Wisconsin. Forages are divided on the basis of NDF concentration, where low NDF $(\mathrm{n}=31$ ) ranged from 36.6 to $52.2 \%$ (mean $=45.1 \pm 3.91 \%)$ and high $\mathrm{NDF}(\mathrm{n}=29)$ ranged from 57.7 to $66.5 \%$ $($ mean $=62.7 \pm 2.61 \%)$. Growth stages are defined as follows: 10 to 19, leaf development; 20 to 29, tillering; 30 to 39, stem elongation; 40 to 49, boot stage; and 50 to 59, heading (Stauss, 1994). Although the combined regression that includes all forages $(\mathrm{n}=60)$ is significant in each case, relationships are spurious for growth stage (A) and canopy height $(\mathrm{B})$ because there is no relationship $(P \geq 0.14)$ associated with the high-NDF group. of MAX ranged from 114 to $205 \mathrm{~mL} / \mathrm{g}$, which means that potential IVGP was almost double in the most active in vitro fermentation compared with the least active. Similar differentials in cumulative IVGP between least and most active fermentations also were observed at the 12 - (43 to $115 \mathrm{~mL} / \mathrm{g}$ ), 24- (73 to $166 \mathrm{~mL} / \mathrm{g}$ ), 36(93 to $187 \mathrm{~mL} / \mathrm{g}$ ), and 48-h (106 to $195 \mathrm{~mL} / \mathrm{g}$ ) incubation time points. Within NDF groups, the differentials were somewhat smaller and are illustrated visually in Figures $4 \mathrm{~A}$ and 4B. Generally, cumulative IVGP was greater within low-NDF oat forages compared with high-NDF forages; the overall group mean for low-NDF forages exceeded the corresponding mean for high-NDF forages by $14,17,16$, and $14 \mathrm{~mL} / \mathrm{g}$ at the $12-, 24-$, $36-$, and 48-h incubation times, respectively. Similarly, the mean $K$ was numerically greater for low-NDF oat forages $(0.069 \pm 0.0116 / \mathrm{h})$ compared with high-NDF forages $(0.055 \pm 0.0110 / \mathrm{h})$.

Correlation Analysis. Within high-NDF oat forages (Table 2), the only correlation between an IVGP parameter and growth stage or canopy height was observed for $K$ and growth stage $(\mathrm{r}=-0.44)$; all other correlations were nonsignificant $(P \geq 0.062)$. Concentrations of NDF were negatively correlated with cumulative IVGP at the 12-, 24-, 36-, and 48-h incubation intervals, but the correlation coefficients became less robust as incubation time increased (range $=-0.58$ to -0.46). Similar trends were observed for hemicellulose, lignin, and ash; however, NDFD, digestible NDF, ADF, cellulose, and lignin:NDF ratio were not correlated $(P$ $\geq 0.054$ ) with cumulative IVGP at any incubation time. In contrast, cumulative IVGP at $12,24,36$, and $48 \mathrm{~h}$ was positively correlated with WSC $(\mathrm{r}=0.42$ to $0.60)$, NFC ( $\mathrm{r}=0.46$ to 0.60 ), and TDN ( $\mathrm{r}=0.55$ to 0.64 ), but correlations again became less robust at longer incubation times. Unlike the 12-, 24-, 36-, or 48-h incubation times, estimates of MAX were weakly correlated with TDN $(\mathrm{r}=0.38)$, and not with any other variable $(P \geq 0.11)$. The IVGP rate $(K)$ was negatively correlated with NDF $(\mathrm{r}=-0.47)$ and hemicellulose $(\mathrm{r}$ $=-0.68)$, but not with other fiber or fiber-digestibility variables $(P \geq 0.051)$; however, positive correlations were observed between $K$ and WSC, NFC, and TDN $(\mathrm{r} \geq 0.43)$. Discrete lag time was correlated positively with ash $(\mathrm{r}=0.40)$ and negatively with WSC, NFC, and TDN ( $\mathrm{r} \geq 0.37$ ). We observed no significant correlations of any gas-production parameter with $\mathrm{CP}(P$ $\geq 0.41)$.

Correlation analysis (Table 3) indicated that relationships between IVGP parameters and growth characteristics or nutritive composition differed sharply for low-NDF fall-oat forages compared with those observed for high-NDF fall-oat forages. In low-NDF fall-oat forages, cumulative IVGP at 12, 24, 36, or $48 \mathrm{~h}$, as well as 

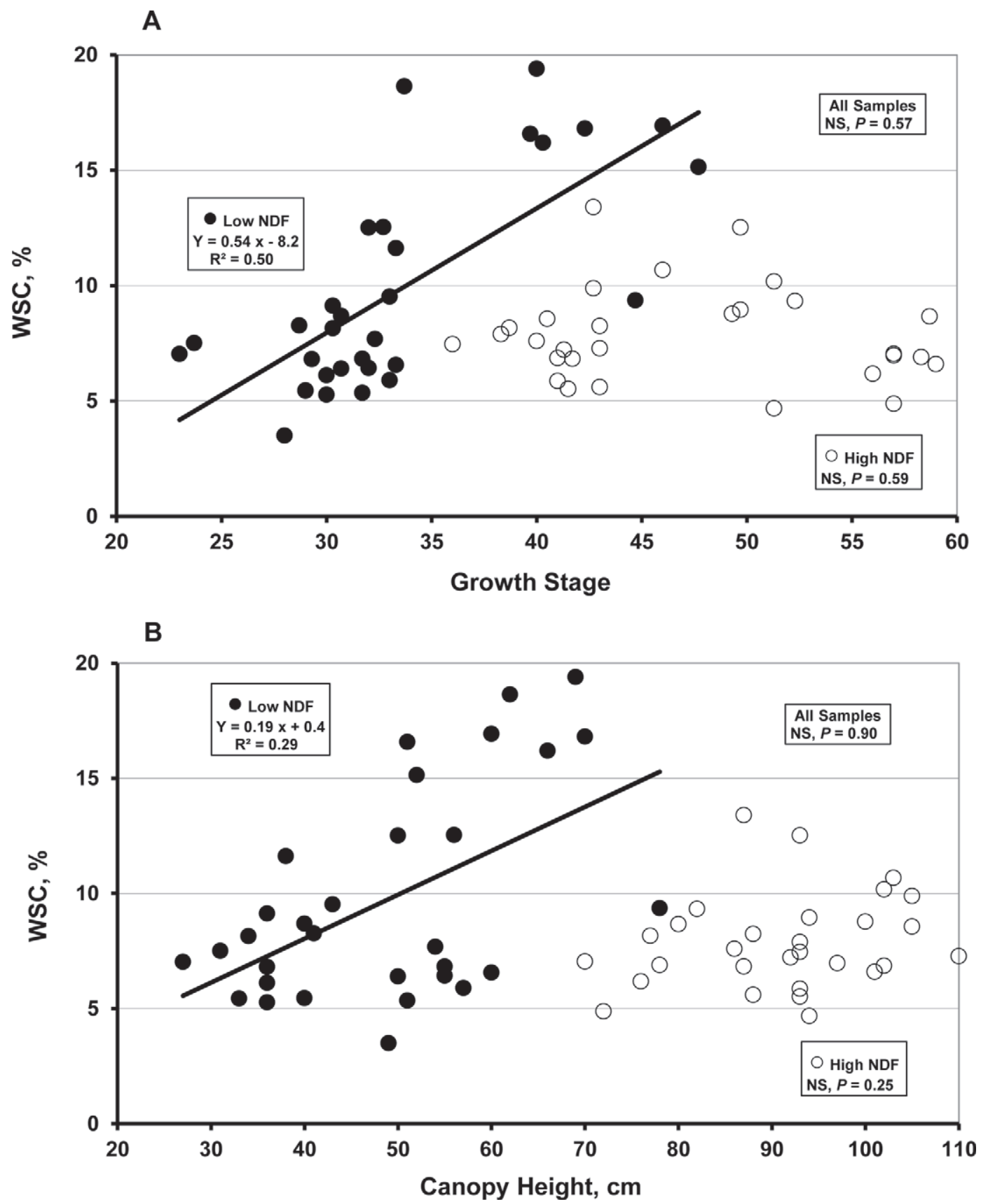

Figure 3. Linear relationships between concentrations of water-soluble carbohydrates (WSC) and growth stage (A) or canopy height (B) for 60 fall-grown oat forages harvested from 2007 to 2009 at Marshfield, Wisconsin. Forages are divided on the basis of NDF concentration, where low NDF $(\mathrm{n}=31)$ ranged from 36.6 to $52.2 \%$ (mean $=45.1 \pm 3.91 \%)$ and high NDF $(\mathrm{n}=29)$ ranged from 57.7 to $66.5 \%(\mathrm{mean}=62.7$ $\pm 2.61 \%$ ). Growth stages are defined as follows: 10 to 19, leaf development; 20 to 29, tillering; 30 to 39, stem elongation; 40 to 49 , boot stage; and 50 to 59, heading (Stauss, 1994).

MAX, were correlated positively $(\mathrm{r}=0.39$ to 0.60$)$ with both growth stage and canopy height. The IVGP rate $(K)$ was not correlated $(P \geq 0.25)$ with either growth characteristic, but discrete lag time was negatively correlated with growth stage $(\mathrm{r}=-0.65)$ and less strongly correlated with canopy height $(\mathrm{r}=-0.36)$. In contrast to high-NDF fall-oat forages, IVGP parameters generally were not correlated with NDF or NDF digestibility. Cumulative IVGP at $12 \mathrm{~h}$ and discrete lag time were correlated with NDFD ( $\mathrm{r}=-0.39$ and 0.45 , respectively), but correlations with all other fiber-related variables were nonsignificant $(P \geq 0.056)$. Concentra- 
A

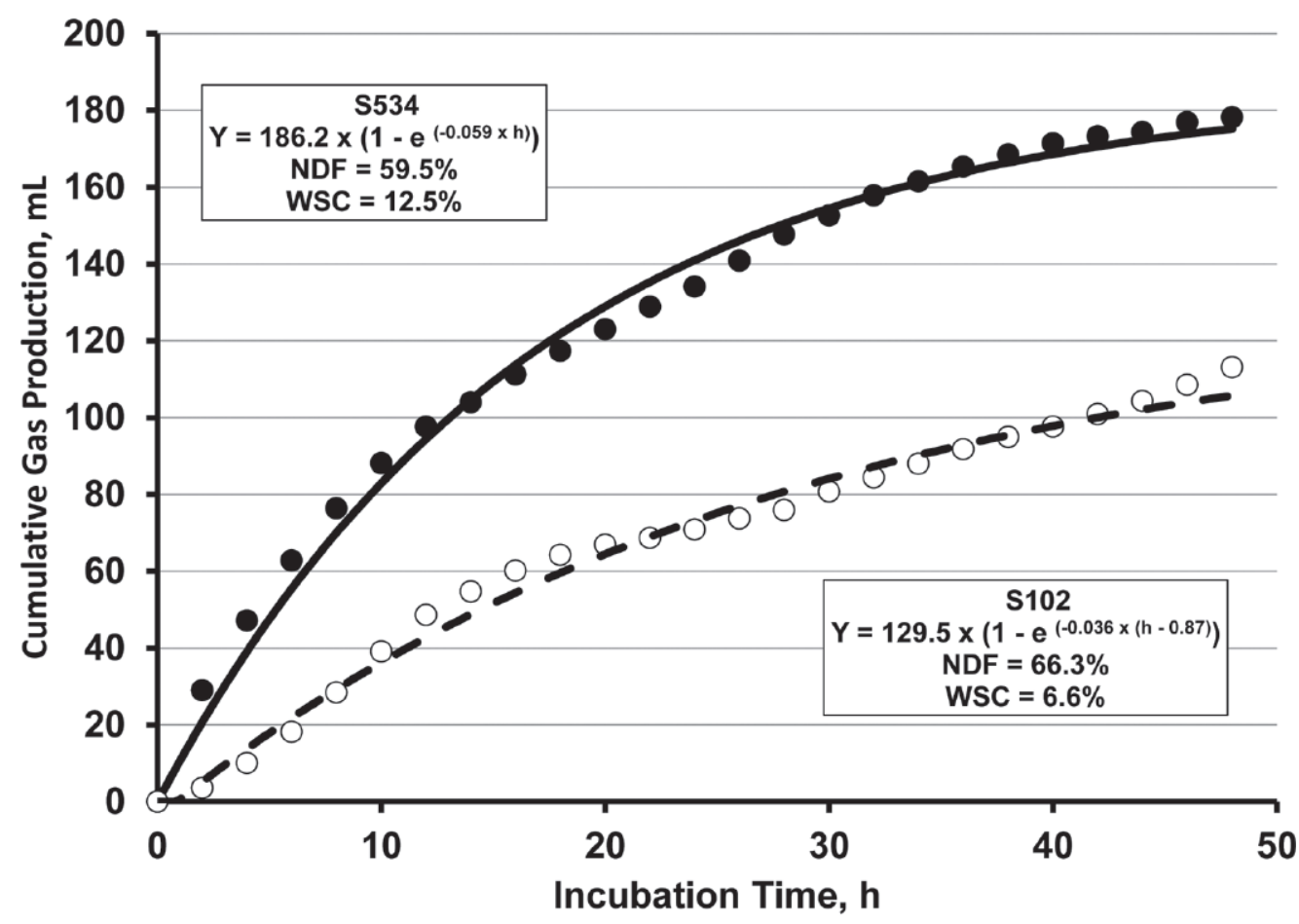

B

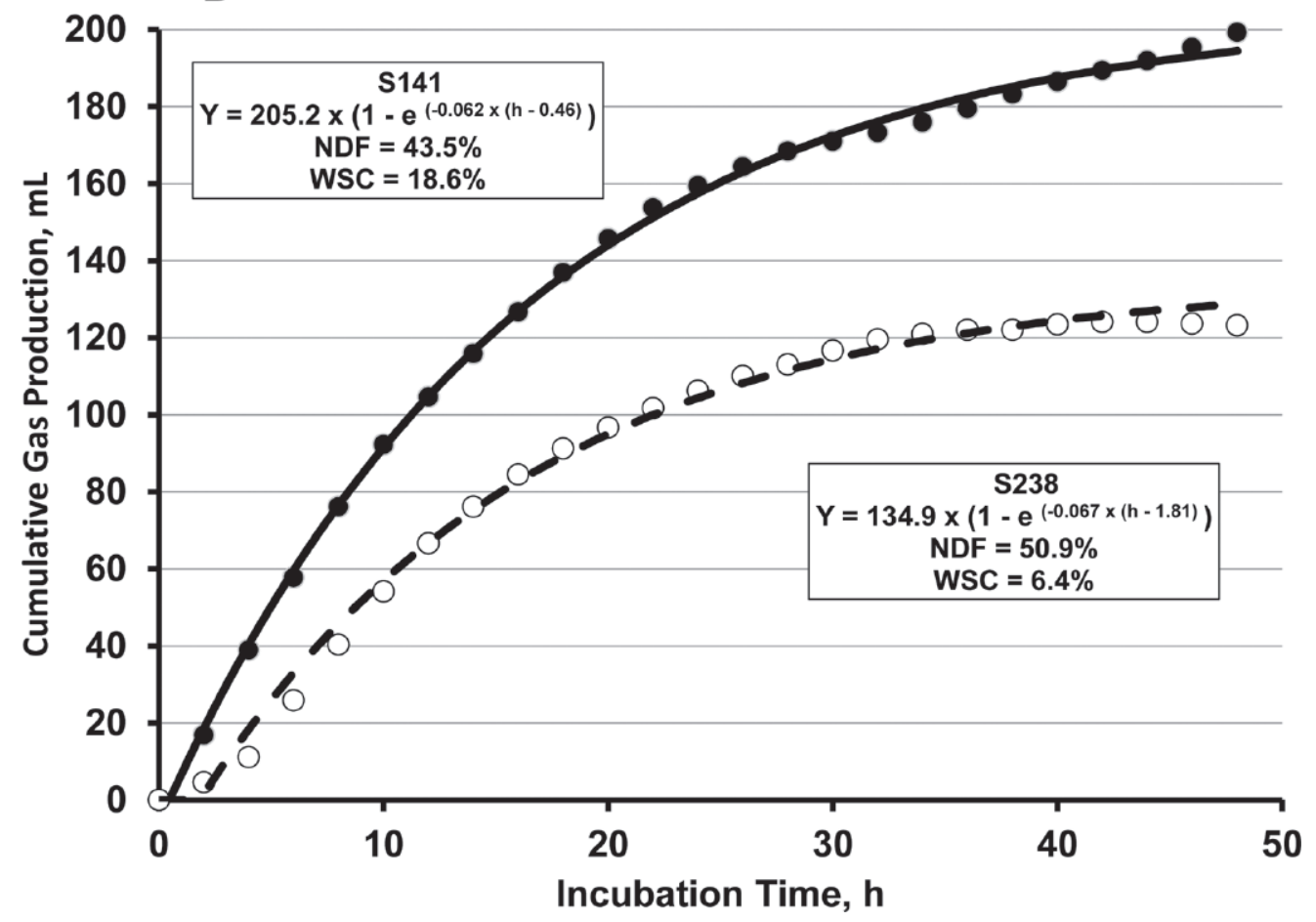

Figure 4. Nonlinear relationships between cumulative in vitro gas production $(\mathrm{mL} / \mathrm{g})$ and incubation time (h) illustrating the range of responses within the high- (A) and low- (B) NDF groups. For both groups, the most active fermentation (samples S534 and S141) is represented by solid circles and a solid regression line $(\bullet,-)$, whereas the least active fermentation (samples S102 and S238) is represented by open circles and a dashed regression line $(\mathrm{O},---)$. All other samples within each NDF group exhibited gas production curves intermediate between these extremes. Fall-grown oat forages were grouped on the basis of NDF concentration, where low NDF ( $\mathrm{n}=31$ ) ranged from 36.6 to $52.2 \%$ (mean $=45.1 \pm 3.91 \%)$ and high NDF $(\mathrm{n}=29)$ ranged from 57.7 to $66.5 \%$ (mean $=62.7 \pm 2.61 \%)$. Individual data points are plotted at 2 -h intervals for clarity of presentation. WSC $=$ water-soluble carbohydrates. 
Table 2. Pearson correlation coefficients of selected field-descriptive, nutritive value, and in vitro gas production (IVGP) data ${ }^{1}$ for high $(62.7$ $\pm 2.61 \%)$ NDF fall-grown oat forages harvested from 2007 to $2009(\mathrm{n}=29)$

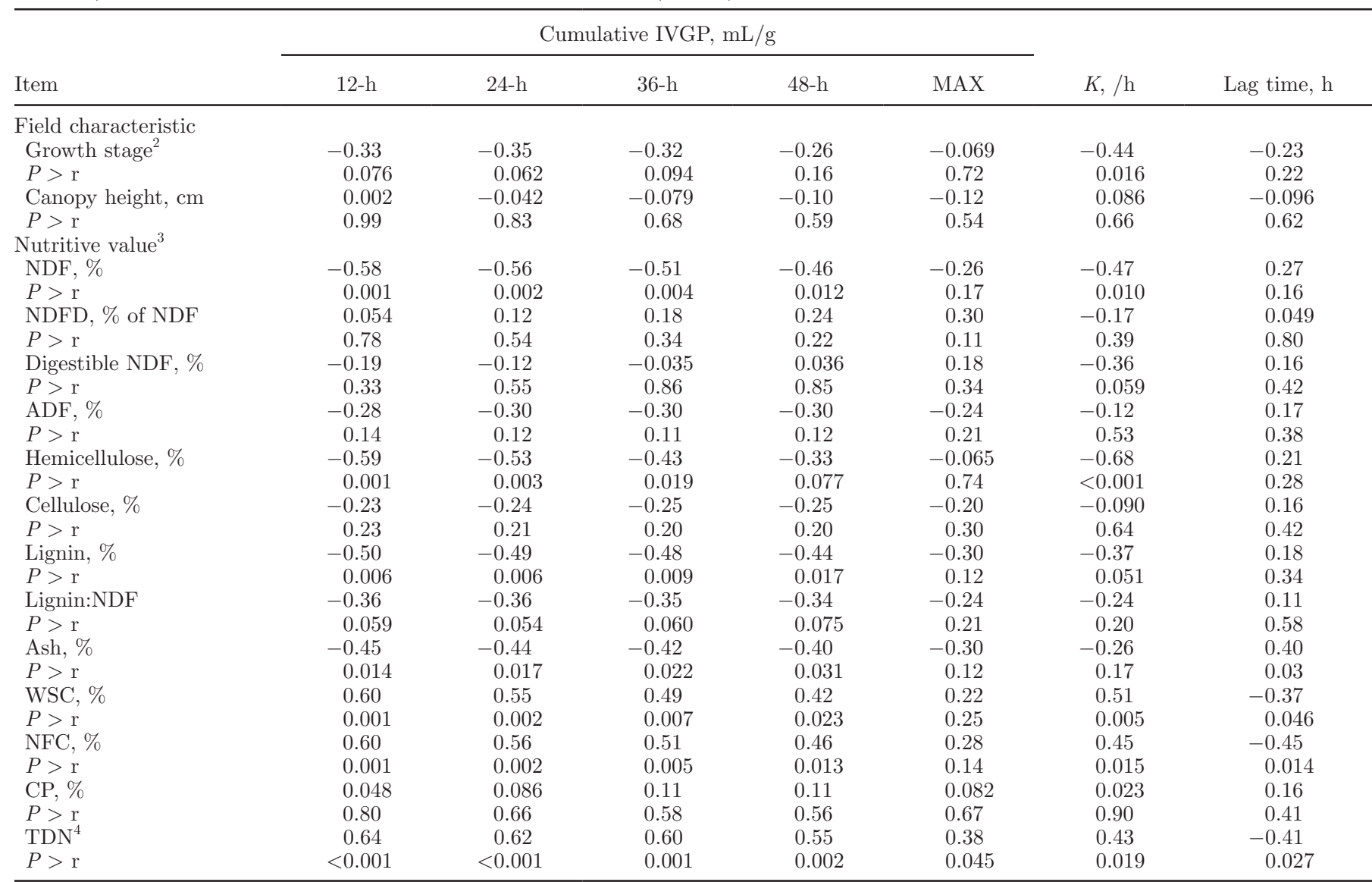

${ }^{1} 12-\mathrm{h}, 24-\mathrm{h}, 36$-h, and 48 - $\mathrm{h}=$ cumulative IVGP after 12, 24, 36, and $48 \mathrm{~h}$, respectively; MAX = theoretical maximum cumulative IVGP based on nonlinear regression; $K=$ rate of IVGP.

${ }^{2}$ Linear scale to describe growth stage of oat plants at harvest (10 to 19, leaf development; 20 to 29, tillering; 30 to 39 , stem elongation; 40 to 49, boot stage; and 50 to 59, heading; Stauss, 1994).

${ }^{3} \mathrm{NDFD}=48$-h in vitro NDF digestibility; WSC $=$ water-soluble carbohydrates.

${ }^{4}$ Calculated with the lignin option for determining truly digestible fiber (NRC, 2001).

tions of ash were negatively correlated $(\mathrm{r}=-0.64$ to -0.52 ) with cumulative IVGP at $12,24,36$, and $48 \mathrm{~h}$, as well as MAX, and positively correlated $(\mathrm{r}=0.54)$ with discrete lag time. Similar responses were observed for $\mathrm{CP}$, and these correlations were especially strong for cumulative gas volumes produced after $24(\mathrm{r}=-0.80)$ and $36 \mathrm{~h}(r=-0.81)$ of incubation. Cumulative IVGP at $12,24,36$, and $48 \mathrm{~h}$, as well as MAX, were strongly correlated with WSC ( $\mathrm{r}=0.73$ to 0.89$)$ and NFC ( $\mathrm{r}=$ 0.74 to 0.90 ), and less strongly associated with TDN $(\mathrm{r}=0.48$ to 0.60$)$. Discrete lag time was negatively correlated with WSC, NFC, and TDN ( $\mathrm{r}=-0.78$ to $-0.48)$, whereas IVGP rate $(K)$ could not be correlated with any measure of nutritive value $(P \geq 0.10)$.

\section{Multiple Regression}

Multiple regression equations that best predicted IVGP parameters differed sharply across NDF groups
(Table 4). Cumulative IVGP at 12,24 , or $36 \mathrm{~h}$ for high-NDF forages included terms for fiber components [(lignin:NDF $)^{2}$, lignin:NDF, lignin, and hemicellulose)], as well as $\mathrm{TDN}^{2}$, but the corresponding regressions for low-NDF forages were positive linear relationships with NFC selected as the sole significant independent variable. Furthermore, regressions at the various incubation times were characterized by very high coefficients of determination $\left(\mathrm{R}^{2}=0.75\right.$ to 0.82$)$ compared with those observed for high-NDF fall-oat forages $\left(\mathrm{R}^{2}=0.43\right.$ to 0.69 ). For cumulative IVGP at longer time intervals (48 $\mathrm{h}$ and MAX), TDN ${ }^{2}$ was chosen as the sole independent variable for the high-NDF group, although these relationships were poor $\left(\mathrm{R}^{2} \leq 0.31\right)$. For low-NDF falloat forages, $\mathrm{NFC}^{2}$, digestible $\mathrm{NDF}^{2}$, or digestible NDF were chosen as independent variables, and regression relationships were much improved, explaining at least two-thirds $\left(\mathrm{R}^{2} \geq 0.66\right)$ of the variation in gas responses. 
As suggested previously, regressions for the low-NDF group were characterized generally by substantially greater coefficients of determination than multiple regression equations selected for high-NDF fall-oat forages. This was true for all regression parameters except $K$, where no potential independent variable met the $P$ $=0.1$ criteria for inclusion into the model for the lowNDF group. Lag times associated with IVGP were related negatively in linear models to NFC and WSC for the high- and low-NDF groups, respectively; however, the coefficient of determination for the low-NDF group was approximately 3 -fold greater than that observed for the high-NDF group.

\section{DISCUSSION}

\section{Factors Affecting Concentrations of NDF}

The relatively limited range in concentrations of NDF (57.7 to $66.5 \%$; Table 1) for selected high-NDF fall-oat forages was the result of specific selection criteria; however, it is somewhat unique that oat samples exhibiting this range of NDF could not be associated with either growth stage $(P=0.36$; Figure $1 \mathrm{~A})$ or canopy height $(P=0.15$; Figure $1 \mathrm{~B})$, given the broad ranges of representation within those growth variables. Samples were selected from plots grown over 3 production years with various establishment and harvest dates; therefore, growing environments differed. Furthermore, morphological development for oat is known to proceed at a much slower rate following late-summer establishment compared with traditional spring planting dates (Contreras-Govea and Albrecht, 2006). However, there was also a relatively wide range in concentrations of WSC (4.7 to $13.4 \%$ ) within this NDF group, which suggests that some dilution of NDF concentrations may have occurred within some high-NDF forages.

The concept of dilution was more evident within low-NDF fall-oat forages, in which NDF was related to both growth stage $\left(\mathrm{Y}=0.40 \mathrm{x}+31.9 ; \mathrm{R}^{2}=0.37\right.$; Figure $1 \mathrm{~A})$ and canopy height $\left(\mathrm{Y}=0.22 \mathrm{x}+34.1 ; \mathrm{R}^{2}\right.$ $=0.54$; Figure $1 \mathrm{~B}$ ) in a somewhat predictable positive relationship. However, ranges for growth stage (23 to 48; vegetative tillering to late-boot stage) and canopy height $(27$ to $78 \mathrm{~cm}$ ) were quite broad and, within this context, the regression relationships with NDF were poor. Although numerous factors may be considered to explain these relationships, it is relatively apparent that at least 2 distinct factors explain why any given oat sample would fit into the low-NDF group. One reason is that low-NDF fall-oat forages fell into the traditional paradigm, exhibiting low NDF concentrations because they were immature, and typically were within the vegetative or early-elongation stages of growth. Often, they also were rapidly growing and exhibited relatively low concentrations of WSC; within the low-NDF group, WSC was related positively to both growth stage and canopy height, with the lowest concentrations of WSC tending to cluster around the jointing (30) stage of growth (Figure 3A). An alternative set of conditions that permitted specific oat samples to meet low-NDF selection criteria occurred within plants that were more advanced morphologically, but exhibited exceptionally high concentrations of WSC, thereby effectively diluting the proportion of the plant composed of structural fiber. Within low-NDF fall-oat forages, concentrations of WSC exceeding $10 \%$ were observed only in plants harvested at the late-stem elongation or boot stages of growth (Figure 1A). It is important to note that these relationships are potentially complex, and a simple cause-and-effect relationship between growth stage and WSC is not necessarily implied. In part, these responses may indicate that the late-stem elongation or boot stages of growth simply coincided with the onset of cold temperatures, which stimulated winter-hardening. However, it also is known that growth stage influences winter-hardening responses in plants (Eastin and Sullivan, 1984), and this has been demonstrated with respect to WSC for fall-grown oat (Coblentz et al., 2012).

\section{A Case Discussion: Two Forages from the Same Research Plot}

These contrasting mechanisms for achieving relatively low concentrations of NDF are clearly illustrated by 2 samples harvested from the same research plot established on August 1, 2008 (Table 5). The first sample (S202) was harvested on September 15 at the late-vegetative (tillering) stage of growth (28) and represents what would commonly be described as high-quality cereal-grain pasture. In contrast, the second sample (S346) was harvested on November 3 at early-boot stage (40). By the November 3 harvest date, the growing interval since establishment had more than doubled (94 vs. 45 d); in addition, canopy height had increased by $20 \mathrm{~cm}$ ( 69 vs. $49 \mathrm{~cm})$, and DM yield had more than quadrupled (4,352 vs. $1,035 \mathrm{~kg} / \mathrm{ha}$; data not shown). In spite of these differences in growth and development, concentrations of NDF, ADF, hemicellulose, and cellulose were nearly identical, and actually declined by 1.1, $0.4,0.7$, and 0.4 percentage units, respectively, by the latter harvest date. Slight increases in lignin (1.10 vs. $0.84 \%$ ), as well as the lignin:NDF ratio (0.024 vs. 0.018$)$ were observed by November 3; however, lignin:NDF ratios on both harvest dates were roughly one-fourth of those reported by NRC (2001) for headed oat hays and silages (0.112 and 0.091, respectively). The static response of NDF across these divergent harvest dates 
Table 3. Pearson correlation coefficients of selected field-descriptive, nutritive value, and in vitro gas production (IVGP) data ${ }^{1}$ for low (45.1 \pm $3.91 \%)$ NDF fall-grown oat forages harvested from 2007 to $2009(\mathrm{n}=31)$

\begin{tabular}{|c|c|c|c|c|c|c|c|}
\hline \multirow[b]{2}{*}{ Item } & \multicolumn{5}{|c|}{ Cumulative IVGP, mL/g } & \multirow[b]{2}{*}{$K, / \mathrm{h}$} & \multirow[b]{2}{*}{ Lag time, $\mathrm{h}$} \\
\hline & $12-\mathrm{h}$ & $24-\mathrm{h}$ & $36-\mathrm{h}$ & $48-\mathrm{h}$ & MAX & & \\
\hline$P>\mathrm{r}$ & $<0.001$ & 0.001 & 0.001 & 0.002 & 0.010 & 0.25 & $<0.001$ \\
\hline Canopy height, $\mathrm{cm}$ & 0.39 & 0.44 & 0.46 & 0.47 & 0.45 & 0.011 & -0.36 \\
\hline$P>\mathrm{r}$ & 0.029 & 0.015 & 0.009 & 0.008 & 0.011 & 0.95 & 0.043 \\
\hline$P>\mathrm{r}$ & 0.52 & 0.50 & 0.49 & 0.49 & 0.49 & 0.97 & 0.50 \\
\hline NDFD, $\%$ of NDF & -0.39 & -0.35 & -0.30 & -0.25 & -0.13 & -0.27 & 0.45 \\
\hline$P>\mathrm{r}$ & 0.030 & 0.056 & 0.10 & 0.17 & 0.48 & 0.14 & 0.012 \\
\hline Digestible NDF, \% & -0.25 & -0.20 & -0.14 & -0.091 & 0.035 & -0.27 & 0.31 \\
\hline$P>\mathrm{r}$ & 0.17 & 0.28 & 0.45 & 0.62 & 0.85 & 0.14 & 0.090 \\
\hline $\mathrm{ADF}, \%$ & -0.020 & 0.005 & 0.021 & 0.031 & 0.044 & -0.045 & 0.087 \\
\hline$P>\mathrm{r}$ & 0.91 & 0.98 & 0.91 & 0.87 & 0.81 & 0.81 & 0.64 \\
\hline$P>\mathrm{r}$ & 0.78 & 0.86 & 0.88 & 0.90 & 0.92 & 0.98 & 0.36 \\
\hline Lignin:NDF & 0.028 & 0.003 & -0.008 & -0.012 & -0.018 & 0.003 & -0.16 \\
\hline$P>\mathrm{r}$ & 0.88 & 0.99 & 0.97 & 0.95 & 0.92 & 0.99 & 0.40 \\
\hline Ash, \% & -0.62 & -0.64 & -0.63 & -0.61 & -0.52 & -0.22 & 0.54 \\
\hline$P>\mathrm{r}$ & $<0.001$ & $<0.001$ & $<0.001$ & $<0.001$ & 0.003 & 0.23 & 0.002 \\
\hline WSC, $\%$ & 0.86 & 0.89 & 0.88 & 0.85 & 0.73 & 0.28 & -0.78 \\
\hline$P>\mathrm{r}$ & $<0.001$ & $<0.001$ & $<0.001$ & $<0.001$ & $<0.001$ & 0.13 & $<0.001$ \\
\hline NFC, $\%$ & 0.87 & 0.90 & 0.90 & 0.87 & 0.74 & 0.30 & -0.73 \\
\hline$P>\mathrm{r}$ & $<0.001$ & $<0.001$ & $<0.001$ & $<0.001$ & $<0.001$ & 0.10 & $<0.001$ \\
\hline $\mathrm{CP}, \%$ & -0.76 & -0.80 & -0.81 & -0.74 & -0.68 & -0.23 & 0.64 \\
\hline$P>\mathrm{r}$ & $<0.001$ & $<0.001$ & $<0.001$ & $<0.001$ & $<0.001$ & 0.21 & $<0.001$ \\
\hline $\mathrm{TDN}^{4}$ & 0.58 & 0.60 & 0.59 & 0.57 & 0.48 & 0.23 & -0.48 \\
\hline$P>\mathrm{r}$ & 0.001 & $<0.001$ & 0.001 & 0.001 & 0.006 & 0.21 & 0.006 \\
\hline
\end{tabular}

${ }^{1} 12-\mathrm{h}, 24-\mathrm{h}, 36$-h, and 48 - $\mathrm{h}=$ cumulative IVGP after 12, 24, 36, and $48 \mathrm{~h}$, respectively; MAX = theoretical maximum cumulative IVGP based on nonlinear regression; $K=$ rate of IVGP.

${ }^{2}$ Linear scale to describe growth stage of oat plants at harvest (10 to 19, leaf development; 20 to 29, tillering; 30 to 39 , stem elongation; 40 to 49 , boot stage; and 50 to 59, heading; Stauss, 1994).

${ }^{3} \mathrm{NDFD}=48$-h in vitro NDF digestibility; WSC $=$ water-soluble carbohydrates.

${ }^{4}$ Calculated with the lignin option for determining truly digestible fiber (NRC, 2001).

suggests that the percentage of structural fiber within the plant was diluted within sample S346, primarily by accumulation of WSC, NFC, or both. Concentrations of WSC were greater by 5.5 -fold (19.4 vs. $3.5 \%$ ) and by 3.2 -fold for NFC (32.8 vs. 10.1\%) within the late-harvested, cold-hardened oat forage; mean daily minimum temperatures for October and November in Marshfield are 1.9 and $-5.2^{\circ} \mathrm{C}$, respectively (NOAA, 2002). Differences in NFC were supported by increased concentrations of maleic (1.50 vs. $0.08 \%)$, malonic $(8.96$ vs. $2.08 \%)$, and fumaric ( 0.40 vs. $0.26 \%)$ acids, as well as reduced concentrations of ash (Table 5).

\section{Effects of Winter-Hardening on IVGP}

For fall-oat samples S202 and S346, the greater concentrations of WSC and NFC found in winter-hardened S346 had a profound effect on IVGP characteristics
(Table 5; Figure 5). Cumulative IVGP after $12 \mathrm{~h}$ of fermentation for S346 was approximately double that of S202 (100 vs. $52 \mathrm{~mL} / \mathrm{g}$ ). Substantial increases in cumulative IVGP persisted through longer incubation times, including a $33 \mathrm{~mL} / \mathrm{g}$ (171 vs. $138 \mathrm{~mL} / \mathrm{g}$ ) difference after $48 \mathrm{~h}$ of incubation. It also is interesting that cumulative IVGP for S346 was essentially asymptotic by $48 \mathrm{~h}$, varying only minimally from MAX (177 $\mathrm{mL} / \mathrm{g}$ ) at that fermentation time point. In contrast, a much larger differential of $38 \mathrm{~mL} / \mathrm{g}$ (138 vs. $176 \mathrm{~mL} / \mathrm{g}$ ) in cumulative IVGP was observed for late-vegetative (S202) oat forage after $48 \mathrm{~h}$ of incubation compared with MAX. Differences in cumulative IVGP, particularly within the first $12 \mathrm{~h}$ of fermentation, resulted in a more rapid estimate of $K$ for S346 compared with S202 (0.074 vs. $0.033 / \mathrm{h})$. Taken in total, these results indicate that a greater proportion of the cumulative IVGP from winter-hardened early-boot stage oat oc- 
Table 4. Multiple regression statistics for in vitro gas production (IVGP) responses predicted on the basis of indices of nutritive value, growth stage, or canopy height for fall-grown oat forages harvested from 2007 to 2009

\begin{tabular}{|c|c|c|c|}
\hline Item $^{1}$ & Regression $^{2}$ & $\mathrm{R}^{2}$ & $P>F$ \\
\hline $12-\mathrm{h}, \mathrm{mL} / \mathrm{g}$ & $\begin{array}{l}\mathrm{Y}=-\left[153,293 \times(\mathrm{LIG} / \mathrm{NDF})^{2}\right]+[11,447 \times(\mathrm{LIG} / \mathrm{NDF})]-(4.84 \times \mathrm{HEMI}) \\
+\left(0.027 \times \mathrm{TDN}^{2}\right)-112\end{array}$ & 0.69 & $<0.001$ \\
\hline $36-\mathrm{h}, \mathrm{mL} / \mathrm{g}$ & $\mathrm{Y}=-(3.51 \times \mathrm{HEMI})+\left(0.033 \times \mathrm{TDN}^{2}\right)+95$ & 0.43 & 0.001 \\
\hline 48-h, mL/g & $\mathrm{Y}=\left(0.036 \times \mathrm{TDN}^{2}\right)$ & 0.31 & 0.002 \\
\hline Lag time, $\mathrm{h}$ & $\mathrm{Y}=-(0.081 \times \mathrm{NFC})+2.27$ & 0.20 & 0.014 \\
\hline \multicolumn{4}{|c|}{ Low NDF $(\mathrm{n}=31)$} \\
\hline $12-\mathrm{h}, \mathrm{mL} / \mathrm{g}$ & $\mathrm{Y}=(2.10 \times \mathrm{NFC})+37$ & 0.75 & $<0.001$ \\
\hline $24-\mathrm{h}, \mathrm{mL} / \mathrm{g}$ & $\mathrm{Y}=(2.56 \times \mathrm{NFC})+69$ & 0.82 & $<0.001$ \\
\hline $36-\mathrm{h}, \mathrm{mL} / \mathrm{g}$ & $\mathrm{Y}=(2.63 \times \mathrm{NFC})+86$ & 0.81 & $<0.001$ \\
\hline $48-\mathrm{h}, \mathrm{mL} / \mathrm{g}$ & $\mathrm{Y}=\left(0.06 \times \mathrm{NFC}^{2}\right)+(1.45 \times$ Digestible NDF $)+83$ & 0.79 & $<0.001$ \\
\hline $\mathrm{MAX}, \mathrm{mL} / \mathrm{g}$ & $\mathrm{Y}=\left(0.053 \times \mathrm{NFC}^{2}\right)+\left(0.043 \times\right.$ Digestible $\left.\mathrm{NDF}^{2}\right)+100$ & 0.66 & $<0.001$ \\
\hline
\end{tabular}

${ }^{1}$ 12-h, 24-h, 36-h, and 48-h = cumulative IVGP after 12, 24, 36, and 48 h, respectively; MAX = theoretical maximum cumulative IVGP based on nonlinear regression; $K=$ rate of IVGP.

${ }^{2} \mathrm{CELL}=$ cellulose HEMI $=$ hemicellulose LIG $=$ lignin; $\mathrm{WSC}=$ water-soluble carbohydrate.

curred earlier in the fermentation because of the heavy accumulation of highly and rapidly fermentable WSC or NFC in the forage. Similar responses have been observed previously; Bueno et al. (2005) observed greater
IVGP from high-NFC (starch) substrates, particularly during the first $36 \mathrm{~h}$ of incubation, compared with lowNFC feedstuffs. Furthermore, Hall and Herejik (2001) reported differences in microbial protein yield from

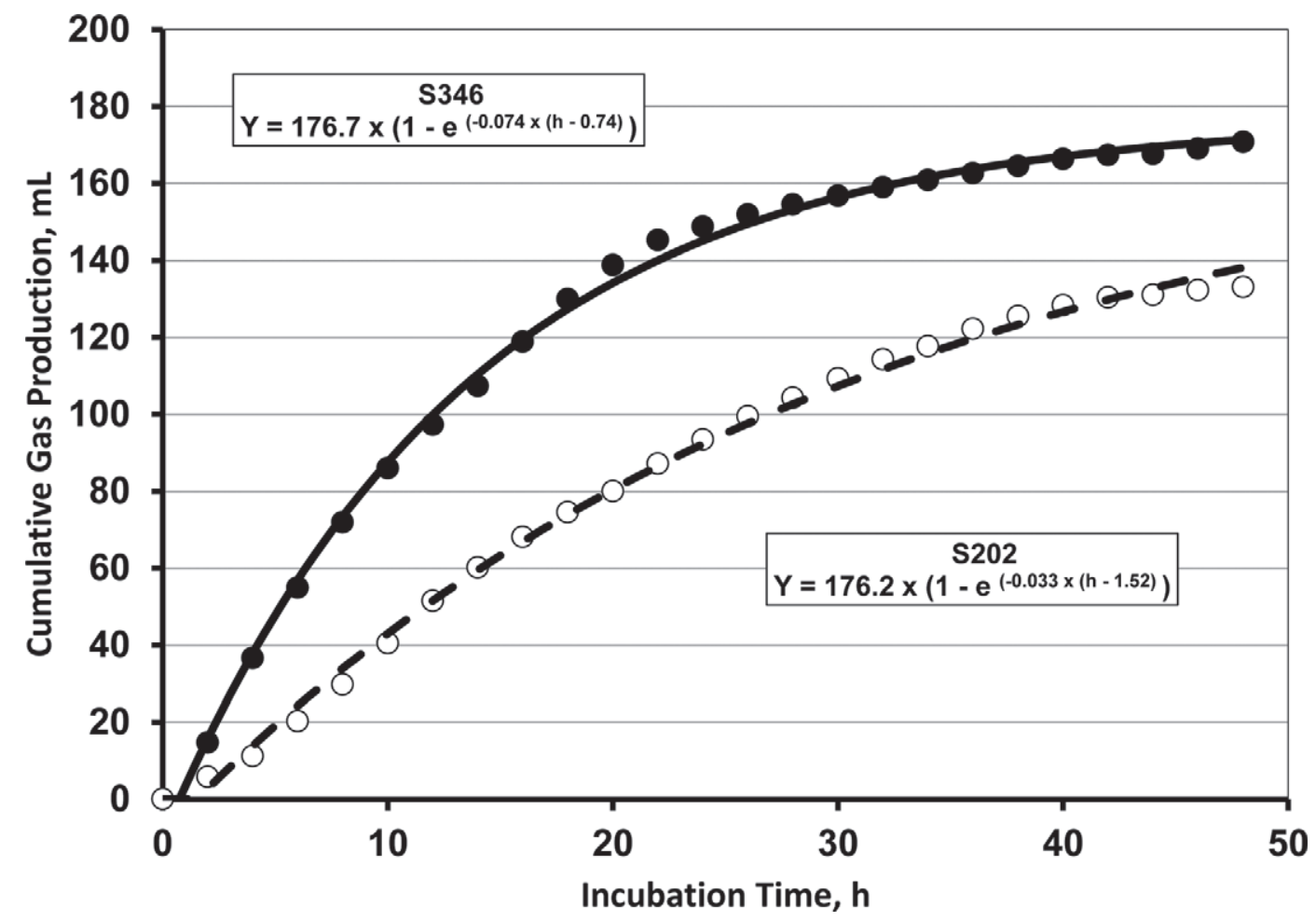

Figure 5. Nonlinear relationships between cumulative in vitro gas production $(\mathrm{mL} / \mathrm{g})$ and incubation time (h) for 2 fall-grown oat forages harvested from the same plot on either September 15 (late-vegetative; sample S202) or on November 3 (early-boot stage; sample S346). Other comparative data are found in Table 5; individual data points are plotted at 2-h intervals for clarity of presentation. 
Table 5. Comparisons of agronomic characteristics, nutritive value, in vitro gas production (IVGP) characteristics, and organic acid analysis for fall-grown oat harvested from the same plot at the late-vegetative (sample S202) or early-boot (sample S346) stages of growth during $2008^{1}$

\begin{tabular}{|c|c|c|}
\hline \multirow[b]{2}{*}{ Item } & \multicolumn{2}{|c|}{ Growth stage } \\
\hline & Late vegetative (S202) & Early boot (S346) \\
\hline \multicolumn{3}{|c|}{ Agronomic characteristic } \\
\hline Planting date & August 1 & August 1 \\
\hline Harvest date & September 15 & November 3 \\
\hline Canopy height, cm & 49 & 69 \\
\hline \multicolumn{3}{|l|}{ Nutritive value $^{2}$} \\
\hline $\mathrm{NDF}, \%$ & 46.3 & 45.2 \\
\hline NDFD, $\%$ of NDF & 75.1 & 58.4 \\
\hline Digestible NDF, \% & 31.9 & 24.2 \\
\hline $\mathrm{ADF}, \%$ & 23.4 & 23.0 \\
\hline Hemicellulose, \% & 22.9 & 22.2 \\
\hline Cellulose, \% & 21.8 & 21.4 \\
\hline Lignin, \% & 0.84 & 1.10 \\
\hline Lignin/NDF & 0.018 & 0.024 \\
\hline $\mathrm{CP}, \%$ & 27.3 & 11.6 \\
\hline WSC, \% & 3.5 & 19.4 \\
\hline NFC, $\%$ & 10.1 & 32.8 \\
\hline Ash, \% & 15.0 & 9.1 \\
\hline $\mathrm{TDN}^{3}{ }^{\%} \%$ & 64.8 & 69.4 \\
\hline \multicolumn{3}{|l|}{ Organic acids } \\
\hline Maleic, \% & 0.08 & 1.50 \\
\hline Malonic, $\%$ & 2.08 & 8.96 \\
\hline Malic, $\%$ & 2.24 & 0.20 \\
\hline Succinic, \% & 0.05 & 0.15 \\
\hline Fumaric, \% & 0.26 & 0.40 \\
\hline \multicolumn{3}{|l|}{ Gas production ${ }^{4}$} \\
\hline $12-\mathrm{h}, \mathrm{mL} / \mathrm{g}$ & 52 & 100 \\
\hline $24-\mathrm{h}, \mathrm{mL} / \mathrm{g}$ & 92 & 145 \\
\hline $36-\mathrm{h}, \mathrm{mL} / \mathrm{g}$ & 120 & 164 \\
\hline $48-\mathrm{h}, \mathrm{mL} / \mathrm{g}$ & 138 & 171 \\
\hline MAX, $\mathrm{mL} / \mathrm{g}$ & 176 & 177 \\
\hline$K, / \mathrm{h}$ & 0.033 & 0.074 \\
\hline Lag time, $\mathrm{h}$ & 1.52 & 0.74 \\
\hline \multirow{4}{*}{\multicolumn{3}{|c|}{$\begin{array}{l}{ }^{1} \text { All units for nutritive value and concentrations of organic acids are in percent of } \\
\text { cated. } \\
{ }^{2} \mathrm{NDFD}=48 \text { - } \mathrm{h} \text { in vitro NDF digestibility; WSC = water-soluble carbohydrate. } \\
{ }^{3} \mathrm{TDN} \text { calculated per NRC (2001) using the lignin option for truly digestible fiber. } \\
{ }^{4} 12 \text {-h, } 24 \text {-h, 36-h, and } 48 \text { - } \mathrm{h}=\text { cumulative IVGP after } 12,24,36 \text {, and } 48 \mathrm{~h} \text {, respect }\end{array}$}} \\
\hline & & \\
\hline & & \\
\hline & & rely; MAX = th \\
\hline
\end{tabular}

in vitro fermentations that included various rapidly available carbohydrates as substrates when $\mathrm{N}$ was not limiting for microbial growth. Although their work suggested that microbial protein production can be altered by carbohydrate source for reasons more complex than simply rate of fermentation, the WSC from fall-oat forages offers some potential for use as a synchronizing agent to facilitate capture of $\mathrm{N}$ compounds released during ruminal proteolysis.

\section{Comments on Estimates of Energy}

The effects of significant accumulations of WSC within winter-hardened early-boot stage oat (S346) were also evident in estimates of TDN for the 2 forages. Traditionally, forage energy content is inversely related to morphological development of forage plants, and it would be assumed that the greatest energy density would be associated with the least mature forage (latevegetative oat, S202). For this forage, concentrations of CP (27.3 vs. $11.6 \%$ ) and NDFD (75.1 vs. $58.4 \%$ of NDF) were distinctly greater than observed for the more mature oat forage (S346; Table 5). However, the greater concentrations of WSC or NFC, as well as corresponding reductions in ash (9.1 vs. 15.0\%) within the winter-hardened early-boot stage forage (S346), improved caloric estimates. Taken in total, a greater TDN estimate was observed for the more mature forage (69.4 vs. $64.8 \%$ ), and this estimate for cold-hardened S346 is comparable to that of normal corn silage (NRC, 2001). This response is unique, representing the unusual situation where forage growth, development, and yield are positively related to energy density. As mentioned previously, this observation does not necessarily imply 
a simple cause-and-effect linkage between growth stage and energy. In part, this observation may represent better synchronization of the more advanced growth stage with cold temperatures, thereby promoting the physiological processes associated with winter-hardening, but it also does not preclude disproportionate responses to cold temperatures based on plant growth stage (Eastin and Sullivan, 1984).

\section{CONCLUSIONS}

Fall-grown oat forages that undergo winter-hardening during the late-elongation or early-boot stages of growth are capable of exhibiting abnormally high concentrations of WSC, NFC, or both, that are typically not associated with traditional spring-grown oat forages or fall-grown oat harvested during the late-vegetative or jointing stages of growth during early fall (without winter-hardening). In this study, concentrations of WSC in winter-hardened oat plants approached $20 \%$ of the total forage DM. As a result, microbial fermentation as measured by cumulative IVGP was accelerated at early incubation times, specifically in response to this large pool of rapidly fermentable WSC. Estimates of $K$ were also more rapid, with greater overall estimates of TDN than observed for vegetative fall-oat forages. Late-summer planting of oat may create the unusual paradigm where forage growth, development, and yield are positively associated with forage energy density. These characteristics suggest that fall oat can possess unique characteristics that could be utilized to extend the grazing season or produce a high-energy, late-season forage in northern latitudes. Although unique in vitro fermentation characteristics of these forages were observed, production trials with lactating cows are needed to determine how to use these unique forages most efficiently in dairy diets.

\section{REFERENCES}

AOAC International. 1998. Official Methods of Analysis. 16th ed., 4th rev. AOAC International, Gaithersburg, MD.

Blümmel, M., H. Steingaß, and K. Becker. 1994. The partitioning of in vitro fermentation products and its bearing for the prediction of voluntary feed intake. Proc. Br. Soc. Nutr. Physiol. 3:123.

Bueno, I. C. S., S. L. S. Cabral Filho, S. P. Gobbo, H. Louvandini, D. M. S. S. Vitti, and A. L. Abdalla. 2005. Influence of inoculum source in a gas production method. Anim. Feed Sci. Technol. 123-124:95-105.

Cherney, J. H., G. C. Marten, and R. D. Goodrich. 1983. Rate and extent of cell wall digestion of total forage and morphological components of oats and barley. Crop Sci. 23:213-216.

Coblentz, W. K., M. G. Bertram, and N. P. Martin. 2011. Planting date effects on fall forage production of oat cultivars in Wisconsin. Agron. J. 103:145-155.

Coblentz, W. K., M. G. Bertram, N. P. Martin, and P. Berzaghi. 2012. Planting date effects on the nutritive value of fall-grown oat cultivars. Agron. J. 104:312-323.
Coblentz, W. K., and R. P. Walgenbach. 2010. Fall growth, nutritive value, and estimation of total digestible nutrients for cerealgrain forages in the north-central United States. J. Anim. Sci. 88:383-399.

Contreras-Govea, F. E., and K. A. Albrecht. 2006. Forage production and nutritive value of oat in autumn and early summer. Crop Sci. 46:2382-2386.

Dennis, F. G., Jr. 1984. Flowering. Pages 237-264 in Physiological Basis of Crop Growth and Development. M. B. Tesar, ed. Am. Soc. Agron., Crop Sci. Soc. Am., and Soil Sci. Soc. Am., Madison WI.

Dubois, M., K. A. Gilles, J. K. Hamilton, P. A. Rebers, and F. Smith 1956. Colorimetric method for determination of sugars and related substances. Anal. Chem. 28:350-356.

Eastin, J. D., and C. Y. Sullivan. 1984. Environmental stress influences on plant persistence, physiology, and production. Pages 201-236 in Physiological Basis of Crop Growth and Development. M. B. Tesar, ed. Am. Soc. Agron., Crop Sci. Soc. Am., and Soil Sci. Soc. Am., Madison WI.

Ford, C. W., I. M. Morrison, and J. R. Wilson. 1979. Temperature effects on lignin, hemicellulose, and cellulose in tropical and temperate grasses. Aust. J. Agric. Res. 30:621-633.

Goering, H. K., and P. J. Van Soest. 1970. Pages 8-11 in Forage Fiber Analyses (Apparatus, Reagents, Procedures, and Some Applications). Agric. Handbook No. 379. USDA-ARS, Washington, DC

Groot, J. C. J., J. W. Cone, B. A. Williams, F. M. A. Debersaques, and E. A. Lantinga. 1996. Multiphasic analysis of gas production kinetics for in vitro fermentation of ruminant feeds. Anim. Feed Sci. Technol. 64:77-89.

Hall, M. B., and C. Herejk. 2001. Differences in yields of microbial crude protein from in vitro fermentation of carbohydrates. J. Dairy Sci. 84:2486-2493.

Leibovich, J., J. T. Vasconcelos, and M. L. Galyean. 2009. Effects of corn processing method in diets containing sorghum wet distillers grain plus solubles on performance and carass characteristics of finishing beef cattle and on in vitro fermentation of diets. J. Anim. Sci. 87:2124-2132.

Mochon, J., and S. Conley. 2012. Wisconsin oats and barley performance tests 2013. Publication \#A3874. University of Wisconsin Cooperative Extension Service, Madison.

NOAA (National Oceanic and Atmospheric Administration). 2002. Monthly station normals of temperature, precipitation, and heating and cooling degree days 1971-2000. Climatography of the United States No. 81. 47 Wisconsin. National Climatic Data Center, NESDIS, NOAA, Asheville, NC.

NRC. 2001. Nutrient Requirements of Dairy Cattle. 7th rev. ed. Natl. Acad. Press, Washington, DC.

O'Hara, M., and K. Ohki. 1973. Studies of the mode of gas production in an artificial rumen and its application to the evaluation of feedstuffs. 3. The mode of volatile fatty acid production, and its relation to the gas-production rate. Jpn. J. Zootech. Sci. 44:432-439.

Siegfried, V. R., H. Ruckemann, and G. Stumpf. 1984. Eine HPLCMethode zur Bestimmmung organischer Säuren in Silagen. Landwirtsch. Forsch. 37:298-304.

Smith, D. 1981. Removing and analyzing total nonstructural carbohydrates from plant tissue. Bulletin No. R2107. University of Wisconsin, Madison.

Stauss, R. 1994. Compendium of growth stage identification keys for mono- and dicotyledonous plants. Extended BBCH scale. Reinhold Stauss, Ciba-Geigy AG, Basel, Switzerland.

Ankom Technology Corp. 2012. Page 44 in Operator's Manual. Ankom Gas Production System. Revised March 5, 2012. Ankom Technology Corp., Macedon, NY.

Van Soest, P. J. 1982. Nutritional Ecology of the Ruminant. Cornell Univ. Press, Ithaca, NY.

Weimer, P. J., Y. Shi, and C. L. Odt. 1991. A segmented gas/liquid delivery system for continuous culture of microorganisms on solid substrates, and its use for growth of Ruminococcus flavefaciens on cellulose. Appl. Microbiol. Biotechnol. 36:178-183.

Weiss, W. P., H. R. Conrad, and N. R. Pierre. 1992. A theoreticallybased model for predicting total digestible nutrient values of forages and concentrates. Anim. Feed Sci. Technol. 39:95-110. 